\title{
What is there behind teachers' reactions? A qualitative study on attitudes with some Brazilian teachers of English
}

\author{
Flavius Almeida dos Anjos, MA, PhD \\ Universidade Federal do Recôncavo da Bahia, Brazil \\ Denise Chaves de Menezes Scheyerl, MA, PhD \\ Universidade Federal da Bahia, Brazil
}

Doi: $10.19044 / \mathrm{esj} .2021 . v 17 \mathrm{n} 22 \mathrm{p} 108$

Submitted: 03 February 2020

Accepted: 15 November 2020

Published: 12 July 2021
Copyright 2021 Author(s)

Under Creative Commons BY-NC-ND

4.0 OPEN ACCESS

Cite As:

Anjos, F. A.; Scheyerl, D. C. M. (2021). What is there behind teachers' reactions?A qualitative study on attitudes with some Brazilian teachers of English. European Scientific Journal, ESJ, 17 (22) 108. https://doi.org/10.19044/esj.2021.v17n22p108

\begin{abstract}
This paper is about teachers' attitudes. We understand 'attitudes' as an evaluative reaction, based on opinions and beliefs one might have. Our objective is to share some data of a qualitative research we conducted with some high school teachers of English, in Brazil. Therefore, we used two instruments of data collection: a questionnaire and an interview. It is an interdisciplinary study, developed under the light of applied linguistics, because upon problematizing social issues related with language, we resorted to social psychology, discourse analysis and critical pedagogy to understand the data. This research is justified because there is still the need to investigate teachers' attitudes, since there has been a great amount of researches on attitudes based mostly on learners, what points to a gap that still needs to be filled. The analysis pointed to some attitudes, such as toward the Self, the language, the methodology, the approach, the logistic factors and to the learners.
\end{abstract}

Keywords: Attitudes, Teacher, English 


\section{Introduction}

Some time ago, signals of approval, disapproval, interest or disinterest, opinions on contents, methodologies and approaches, on the part of the learners, almost never, were taken seriously. In this line of thought, upon talking about learners' opinions on the learning process of a foreign language, Rajagapoplan (2003) alerts on the neglect and the disinterest on the part of many researchers in dealing with opinions that should guide school curriculum, the adoption of proper methodologies and goals to be achieved in the educational path. Without shadow of doubt, what we are initially put on the agenda is about attitudes, which need to be regarded.

More recently, 'attitudes' have been of great interest on the part of some researchers, mainly because many of them have agreed with the fact that success in learning a language is directly influenced by what learners think and how they evaluate the target language, the culture and the learning environment (Gardner, 1985; Hosseini, Pourmandnia, 2013). Some studies have focused on figuring out how learners evaluate teachers' role, the methodology they use, their approach etc (Anjos, 2013, 2018, Gardner, 1985). This kind of evaluation is important in the sense that the evaluation we make on the facts and events should be aligned with what students think as well. About this Freire (1996, p. 64, our translation) says:

This requires from me a permanent critical reflection about my practice, through which I am going making the evaluation of my own practice with learners. The ideal thing is that, sooner or later, it is invented a way through which learners can take part in the evaluation.

What Freire (1996) draws attention is concerning attitudes, acknowledging the relevance of learners' voice to improve the educational process. He talks from an area where not always learners' voice is taken into account. However, Social Psychology has been the area in which researchers have dedicated themselves to analyze attitudes in the educational field. About this:

Attitudes have been and indeed continue to be the focus of a great deal of research throughout the social sciences. In particular, attitude has been a central exploratory variable in the field of social psychology more than in any other academic discipline (Mackenzie, 2010, p. 19). 
Many of these studies, conducted under the light of Social Psychology, have as base learners' attitudes. From this perspective, many other factors have emerged, shedding light on the educational setting, which is permeated by identities, beliefs, feelings etc. Anjos (2018) mapped a group of researches on attitudes around the world, eliciting the relationship among attitudes and some factors. Next we share table 1 with some of these researches:

Table 1: researches on attitudes.

\begin{tabular}{|l|l|l|}
\hline \multicolumn{1}{|c|}{ CONTEXT } & \multicolumn{1}{|c|}{ RESEARCHER(S) } & \multicolumn{1}{c|}{ TYPE OF PARTICIPANTS } \\
\hline Tokyo & $\begin{array}{l}\text { Tsuda (2003) } \\
\text { Matsuda (2003) } \\
\text { Yee Young (2006) }\end{array}$ & Undergraduate students \\
\hline China & $\begin{array}{l}\text { Wu Man-Fat (2004) } \\
\text { Liu (2007) }\end{array}$ & Undergraduate students \\
\hline United Kingdom & Adolphs (2005) & Undergraduate students \\
\hline Lebanon & Abidin et alii (2012) & High school students \\
\hline Pakistan & Siming et alii (2015) & Undergraduate students \\
\hline Iran & Vaezi (2009) & Undergraduate students \\
\hline Malasya & Ahmed (2015) & Undergraduate students \\
\hline Turkey & Karaham (2007) & \begin{tabular}{l} 
Private high school students \\
\hline Brazil
\end{tabular} \\
& $\begin{array}{l}\text { Ribeiro (2006) } \\
\text { Anjos (2013; 2018) }\end{array}$ & $\begin{array}{l}\text { Undergraduate students } \\
\text { High school and undergraduate } \\
\text { students }\end{array}$ \\
\hline
\end{tabular}

Source: The Authors, based on the references used in this paper.

Among other things, these studies tried to understand why learners liked or disliked learning English, their positive and negative reactions toward the learning of English, their reactions toward different accents, their feelings about the native speakers, their beliefs on learning/teaching English, their orientation to learn English and the effects of motivation and demotivation to learn English.

However, it is relevant to understand teachers' attitudes as well. In this line of thought, the objective of this paper is to share some data of a qualitative research we conducted with some Brazilian teachers of English, when we intended to figure out their attitudes. Its relevance lies on the fact that there is still the need to investigate teachers' attitudes in order to shed light on the learning/teaching process, to improve it, since attitudes are functionally relevant to people for a number of reasons, such as to contribute to knowledge organization and to guide approach (Mackenzie, 2010).

Thus, this paper is divided into four sections, besides this introduction. First, we make a literature review on attitudes, highlighting some conceptions on the term, which support our own ideas. Secondly, we describe briefly the 
participants of the research and the methodology we used to collect the data. Thirdly, we share some data with our comments on them. And finally, we present our final remarks. Next, let us start with some concepts of attitudes.

\section{Basis to understand attitudes}

We think applied linguistics is a proper area to investigate 'attitudes', because through its theoretical framework it is possible to analyze them with a high level of confidence, since its interdisciplinary feature guarantees an understanding through different lenses. To do that, we used the tenets of social psychology, critical pedagogy and discourse analysis. Let us briefly say something about these areas.

Social psychology has been fundamental to understand 'attitudes' in the educational setting. The researches, developed in this area, get to explain the relationship of attitudes with feelings, identities, aptitude, motivation, demotivation and orientation to learn a language, what has given support to understand several educational scenarios. Gardner (1985) is one of the exponents of this area. In Social Psychology and Second Language Learning, he develops arguments which explain the relationship of learners' attitudes and other factors. His reasoning in centered in the notion that the learning of a language is a social psychological phenomenon, permeated by many factors, among which are attitudes, that, according to him, influence the success with which a language is learned. Thus, his goal was to explain why attitudes and motivation play a central role in the process of learning a language and the nature these roles play. In this perspective, it was possible to go through Social Psychology theoretical paths, to build the base of this study. As attitude is a construct materialized in the discourse, inevitably we had to get into this world.

Concerning this, we agree with Pennycook (2006) when he says that it is beginning to emerge in applied linguistics the understanding of the discourse role in the subject constitution, as multiple and conflicting and his reflexivity in the production of knowledge. To do this research, we invited those ones who live the educational practices to give opinion about this, what is an essential dimension in applied areas (Moita Lopes, 2006). Therefore, Discourse Analysis is also an area that became essential to carry this study out, because the data we got from the questionnaire and the interview, as discourse sources, went through an analysis process, so that we could verify the teachers' attitudes.

We also agree with Fairclough (2001) when he states that discourse analysis is a method. For him, a researcher can decode a corpus, decompose it into classes, as we did in this study, when we established categories to analyze the data. In this perspective, we considered as a paradigm the concept of 
'discourse' defined by Fairclough (2001). For him, 'discourse' is a social practice shaped and constrained by the social structures, shaped by institutional specific social relationships. Fairclough (2001) points out that the discourses contribute to the construction of social identities and subjects positions as well as to the construction of social relationships among people. However, something else was missing to analyze the data of this study and that is way we decided to go through the critical pedagogy path.

To analyze teachers' discourse it was necessary to read theoretical contributions from critical pedagogy to understand the discursive pattern we got. Therefore, we started with the notion teachers' discourses are placed, contextual and they reflect the relationship these teachers establish with the contexts they act. Thus, discourses of revolt, complaint, apathy, fanciful and naive might emerge, which can signal the need to rethink the educational setting and the practices engendered in it. Upon taking part in a research like this, teachers can be lead to (re)think their performances, to think of alternatives which can change their scenarios.

Thus, these teachers problematized the contexts where they work. In this sense is that Giroux (1997) defends an intellectual transformer posture on the part of the teachers and ensure that this concept works as critical benchmark so that teachers question the interests which are registered in the institutional daily practices, experienced and reproduced at schools. It seems that it is in this sense that Pennycook (1998) alerts that critical pedagogy aims to understand and criticize the pedagogical practices of schooling and the society as whole. Doing so, the educator assumes a critical role, that intends to question the educational setting and that is why this stands for a threat to the constituted powers (Rajagopalan, 2003). Somehow or other, this study made possible that teachers, from the questions we used, thought of their practices.

Having made these points clear, from now on, we share some concepts of attitudes, mainly the ones we found in social psychology.

In the educational setting, learners and teachers' attitudes, many times, go unnoticed. Even teachers disregard or they do not pay attention at their own attitudes. Most of them seem not to take their attitudes into account. Though this knowledge can support them in conducting their practices.

Thus, our aim is to analyze how a group of Brazilian teachers of English evaluate their own practices and this is about attitudes. We both think it is proper to share some concepts of attitudes to understand our thought.

One of the most influential definitions of 'attitude' comes from social psychology, when Gardner (1985) defines it as an evaluative reaction towards something or somebody, based on beliefs and opinions one might develop. For him, the success in acquiring a new language is strongly influenced by our 
attitudes. His studies shed light on the way we understand 'attitudes', when he classified them into three components: cognitive, affective, and behavioral. These components correspond respectively to our beliefs and thoughts, feelings and emotions and the adoption of a particular learning behavior.

In fact, Allport (1954) is the pioneer to define 'attitude', when in the 1950 s he states that 'attitude' is a state of neural and mental readiness, framed by experiences, which have a dynamic influence on the answers an individual might have, regarding objects and situations with which this individual is involved.

Mckenzie (2010) defines 'attitude' as a hypothetical construct, something that cannot be directly observed, but it can be inferred from observable responses towards objects, individuals, institutions, events and abstract ideas. Based on a mentalist view, he assures:

Most attitude research has taken the mentalist view. A mentalist approach views attitudes as an 'internal state of readiness', which when aroused by stimulation of some sort will affect the responses of the individual. The implication is that attitudes are not directly observable but can only be inferred from respondents' introspection. It is for this reason that researchers must rely upon the individuals themselves to report their perceptions (MACKENZIE, 2010, p. 21-22).

For Hosseini and Pourmandnia (2013), 'attitude' is a disposition or tendency to answer positively or negatively towards a certain thing, such as an idea, an object, a person or a situation. They think that 'attitude' towards a certain language and the way learners perceive that language have a great influence on their performances on the language itself.

For Ahmed (2015), 'attitude' can be defined as a collection of feelings towards language use and its status in society. This author draws attention to the fact that learners' attitudes play a vital role in maximizing learning and teaching. He also mentions that our feelings -good, bad or neutral- can nurture or hinder the effectiveness of the learning process.

Anjos (2018) defines 'attitude' as a favorable or unfavorable positioning toward something or somebody. He investigated, through an ethnographic research, 91 undergraduate students, from Brazil, who studied English, in order to verify their attitudes. He found out a strong relationship among attitude, motivation, demotivation and the logistic factors, such as the (low) workload of the subject, the (improper) methodology used to teach English, the heterogeneity of the group etc. In this way, we have to say that 
we still keep on agreeing with him, since for us, the educational setting as a whole will exert an influence on how learners will react in it.

For the educational setting, we understand attitudes as a way to know it even better, since they are related with many factors that address learners in the educational path, that is to say, how they behave, their persistence and effort to fulfill an action. What, by its turn, is related with motivational components, such as 'self-confidence' and 'conquest need' (Dörneyi, 1994).

We finish this section here and next we briefly describe the participants and the methodology of this research.

\section{Participants and methodology}

This research was conducted with some teachers of English, from private and public schools, in Bahia state, Brazil. Three of them hold a course in pedagogy; one holds a course in modern languages, another one studied administration and one is still studying modern languages.

This study was properly protocoled at Plataforma Brasil, as the current academic formalities require, and it had approved opinion by the Ethic Committee, from the Recôncavo of Bahia Federal University (UFRB), which number of certification is (CAAE) 03849718.2.0000.0056. The proceedings adopted in this research obeyed the ethic criteria concerning research with human beings, according to the resolution CNS N $\mathrm{N}^{\circ} 466$ de 2012.

We classify this research as a qualitative study, since we gave our interpretation on the data we collected. Actually, this paradigm of research has been used increasingly in the educational field (Cançado, 1994), because teachers have been interested by the qualities of the educational phenomena in detriment of the numbers, that, many times, camouflage the human dimension of the educational phenomena at schools. (Telles, 2002).

This type of research seems to be aligned with what Corbin and Holt (2015) call 'Theory based on data', a kind of methodology that generates theory, which are elaborated by participants. They say the most important thing concerning this methodology is how people live and ascribe meaning to the events, by asking them different types of questions. In this perspective, to get the data we used two instruments of data collection: an interview and a questionnaire.

Therefore, the method we used is of ethnographic stamp, since upon using these instruments, we intended to understand some teachers' behaviors, within a certain context. Thus, we aimed at describing and interpreting the culture and behavior these teachers have.

For this purpose, basically we created some categories to generate the data: 1. Attitudes about the teacher (the Self), 2. Attitudes toward learners, 3. Attitudes toward the teaching and 4. Attitudes about learning languages. The 
fact is that we made a cut in the data, since we are still investigating beliefs as well. Though we are also studying their beliefs, we are not going to include them here. In the next line we present some data which show teachers' attitudes, as we intended.

\section{Results}

\section{The questionnaire data}

\section{a) Attitudes about the teacher (the Self)}

We asked the teachers How do you feel teaching English? P1 reveals to feel herself satisfied (attitude) as an English teacher and signals that the reason why she has this attitude it is because she wanted to become the teacher of English she had in high school. She still evaluates her performance using the verb 'to love', evidencing that her attitude about teaching English is highly positive:

P1: [I feel myself] fulfilled, because I love teaching English and I remember that in my adolescence I had a desire to be just like my teacher, because she knew "everything" in English.

On the other hand, P2 does not evaluate his performance as a teacher positively. About this, he mentions that the number of students per class, because the classes are overcrowded, and the lack of interest of some learners make the process hard. So, he says it is 'difficult' to teach English taking into account the logistic factors, what, to our mind, generate his negative attitude toward the teaching process.

P5 feels himself abandoned by saying that 'the material is improper', 'teachers lack resources' and 'teachers do not have any kind of support'. We observe that these claims proceed, because some of them told us that in spite of having books, they do not meet a local perspective and there is not anybody in the school to take the doubts that often emerge. Thus, we can assure that without support to teach English, teachers face challenges which provoke negative attitudes toward the process (Walker, 2004).

P6 feels himself 'insecure' and 'uncomfortable' to teach English, and he ascribes these attitudes to his limited knowledge. Based on this, we may assure that acquiring knowledge, getting proper background is essential to have a good performance and to avoid negative attitudes toward the Self.

P6: I love teaching the English language. But, sometimes, I feel myself uncomfortable, that is a bit insecure, since I feel myself limited. 
We also asked them: what would be the good teacher of English profile? P1 evaluates that a good teacher of English teaches in different ways, striving not to make the process mechanic:

P1: I understand that the teacher is the knowledge facilitator. Thus, a good English teacher is that one who seeks several ways to teach students, in a pleasurable way and not mechanic.

P2 evaluates that the one who avoids teaching the language systematically but introduces it in a contextualized and reflective way has a good profile. However for P3 the good teacher works recreationally. Based on this discourse we can infer as well that $\mathrm{P} 3$ also expresses his belief, evidencing the fact that beliefs are constructs which one joins (Garbuio, 2006), eliciting the relationship between attitudes and beliefs. Look at his statement:

P3: I believe that a good English teacher should work in a playful way, with games, dialogs, songs, etc.

P4 used some qualifiers to answers this question: 'creative' and 'democratic'. He also said that this professional should instigate on learners the desire to learn more the language. This leads us to say that for P4 it is the teacher's role to activate learners' motivation, so that they can be engaged in the learning process.

P5 said a good teacher works and relevant contents, contextualizing them to include learners, what allows us to say that for P4 contextual factors are of great value to be a good teacher of English. In this line of thought, Freire (1996) alerts on the fact to discuss with the students the true reality associated with the subject one is teaching, even the aggressive ones, pursuing an intimacy among learner's social experience and the curriculum knowledge. For P6 a good teacher of English should be 'agile' to build knowledge together with students, to make them feel confident:

P6: A dynamic teacher, who builds together with students, open space so that they feel comfortable.

P6's evaluation on the profile of a good teacher seems to be related with what Dörnyei (1994) calls on the language level to motivate students 'develop students' self-confidence' by involving them in more favorable easier activities and using confidence- building tasks.

These are our comments on the first category. Next, we share some data concerning the second category: attitudes about teaching. 


\section{b) Attitudes about teaching}

We asked the teachers "how would a good English class be?" For P2 when learners are 'interested' a good English class takes place. We noted that her attitude about teaching is based on learners and not in herself, her choices and practices, what, to us, sounded a bit without a self-reponsability towards the process.

Both P4 and P5 think that a good English class is 'dynamic'. Their beliefs allow us to say it depends on the teacher to do a good class. Upon using a qualifier, what signals their attitudes, we understand this reaction as a view of what is active, energetic and funny as a way to active learners' motivation, ratifying the relationship between attitude and motivation (Gardner, 1995, ANJOS, 2018).

For P5 and P6, the classes should be contextual; it should approach learners' reality, to make them feel part of the reality they are involved in. This has to do with local practices to teach a global language that Kramsch and Sullivan (1996) defend.

Here are their statements:

P2: When all learners took part and show interest.

P3: With a dynamic teacher, who had knowledge necessary to encourage the student, motivating him.

P4: Very dynamic.

P5: A dynamic class, with meanings concerning contents and the social context.

P6: A class that was closer to the learner's reality. Where he feels himself part of that universe.

Next, we share our interpretation based on the second category: attitudes about learning languages.

\section{c) Attitudes and beliefs about learning languages}

\section{at school?}

We asked the teachers: Do you believe it is possible to learn English

P1 evaluates as 'impossible' to learn English at high school. She thinks students will only learn grammar is this space. She argues to learn in fact the language, learners will need a language course out of school. This allows us to say that P1 holds an attitude of discredit to schools: 
P1: No. I believe that in classroom learners will learn the linguistic and grammatical structures as whole. However, I believe that courses for conversation will be more indicated to learn a foreign language.

For P2 to learn English at school, it is necessary to change the system, what signals her negative attitude toward this setting.

On the other hand, P6 thinks it is possible to learn English in the mentioned setting, though he evaluates it is 'difficult', because it is necessary discipline and dedication to do so.

Another question we used was: If there is, which is the biggest problem that impedes the English language teaching/learning process, in the places where you teach it?

P1 thinks what makes the process difficult is the initial contact with the language, which may move students way from the process. Based on this, we understood the role teacher has to get students closer and involved in the learning process.

Three of them, P2, P3 and P5 ascribed the difficult to learn English to some logistic factors, such as proper material and technological researches. In this line of thought, P6 said that big groups of students are the biggest problem teachers can face. Besides that he describes that a space with so much heat, exceeded number of learners in a classroom converges to an inadequate learning space.

We asked the teachers later: How do you think your students learn better?

P2 based his answer in the development of the skill listening and speaking.

P4 said to make students learn it is necessary dynamic classes. What was not clear to us, what meant by using 'dynamic'.

Next, we share the interview data.

\section{The interview data}

\section{a) Teachers' attitudes} fail?

We also asked the teachers: How do you feel when your students

P1 says she gets angry whenever her students fail, though she reveals this is not her fault, because she prepares evaluations and activities and many learners neglect her work:

P1: I get quite angry, because, in fact, I pursuit the best way to develop my charging methodologies, in terms of grades, of values 
and, many times, [the students] neglect, mainly concerning homework, seminars and, normally, they fail because of this, I don't disapprove much in exams.

Sadness is the feeling P2 said to have when his students fail in English. Let us see his statement:

P2: I get... little sad and I evaluate myself, but significantly through a reflection.... where was the fault, if it was in the teacher... Sometimes, I am able to identify that some students, because of their deficiency of base, because I have many students like this, who comes with a deficiency of base, of literacy, and he doesn't have a correct interpretation of the text, because it was a deficiency of base.

P5 evaluates that when his students fail in English, he feels himself incoherent with the pedagogical proposal. It seems that P5 admits that the failure is a consequence of his learners' negligence. Somehow we questioned ourselves whether teachers never start an evaluation from themselves, thinking of their methodologies, approaches and materials, which when improper may cause unpleasant consequences. Here it is his statement:

P5: I feel as if everything I did had no meaning, it wasn't worth doing that, mainly because of neglect on the part of them [students].

\section{b) Attitudes about teaching}

Another question we used to investigate their attitudes was: What do you think about your classes?

P2 revealed to be himself 'satisfied' with his classes. It seems that this evaluation is because he is applying a new approach with his students, with texts, which the topics are of their interest, and because of this, he evaluates that his classes are good. In spite of this, he told some students said that his classes were repetitive and boring, what, by its turn, has made him reflective, what elicits change of practices. Next, it is his statement:

P2: My classes... ahh, there are days I feel even satisfied, I feel that the class is working, sometimes even when I put this in practice, because I am trying to make this adaptation, that is a text, a curiosity, something that they feel more pleasure to look for, because they feel it is new, they feel it is something interesting 
within that context, that, at the same time, shows the English language and they don't stay stuck only in the language, but also in the theme the text approaches. So, when the class is in this perspective, it works well. But there is class like this, there are some students who say ah! Teacher this is tiring, this is repetitive. And this makes the teacher reflect. Actually, it is necessary to renew always, it is necessary always a new thing.

P5 evaluates that his classes are interesting or quite interesting. However, she thinks some other classes need to be improved, although he did not mention the reason:

P5: I classify my classes hum..., I cannot generalize all of them, but I evaluate some as interesting, some quite interesting and others, I need to improve them.

They were asked as well: is it difficult to teach English?

P1's attitude towards this question was that the difficult is on the understanding, on the part of the learners, that the language is not difficult. However, we understand that it is not so unpretentious to affirm that, because learners might have different difficulties to deal with a new language. We also think P1 failed to say how a teacher can show students the language is not difficult. Next it is P1's statement:

P1: Not much, because, sometimes, the difficult is so that students can understand, but try to show them that the language is not something so difficult, it is inserted in everyday life, in many ways.

P5 also agrees with the assumption that it is difficult to teach English and ascribed this difficult to the teaching material support. We think that this logistic factor is one of the most important for teachers to conduct their classes, mainly in contexts where there is a large number of students per class, what makes the environment improper to learn a language easily. As a result, as P5 said, learners complain on the practice the teachers adopt, though the problem is located in another place. Here it is P5's statement:

P5: Yes! It's a contact with a new language, isn't it? Different of everything you did, once again harping on the same string, you need specific material for that, and we don't have it, you need a pedagogical support for that as well, and we do not have it. So, 
when there is nothing, so, it is even difficult, because you will have to search out. If you don't want your classes with your students always complaining of the same thing, not to stay with the same old thing, so you have to search. Once you have an structure within the classroom, with all this support, the work, of course, will go well.

\section{c) Attitudes about learning language}

We used the same question from the questionnaire to verify the maintenance of their answers or not: Is it possible to learn English at high school?

For P1, students only will learn English at language courses. Her attitude ascribes to the language course the task to teach English in detriment of the school, that is to say, she acknowledges language courses as the best place to learn a language. With this evaluation, she mistakenly discredits basic education at schools:

P1: I believe that at school it is only a way so that they can feel motivated, but I believe that courses, as they work more with conversation, it is the best place so that they can speak the language.

We insisted on the question: how do students learn better?

For P2, through contextualized classes, reflection based on texts linking them with local reality, students learn better. Besides that, she puts the speaking skill as an ability that makes students learn more:

P2: [...] Through reflective texts, many times, related with their contexts, their realities, so that when there is a translation, they can understand their livingness whithin that reality, whithin that context, and highligting pronunciation and asking them to speak as well, because I always say to learn it is necessary to speak, because it is a language and we learn it by speaking it.

P5 also agrees with the fact that approach a language in local perspectives, focusing on activities may interest students, they can learn better:

P5: Generally I create strategies, taking something of their interest, working with information of the community, using some texts of different types, such as newspapers, some written, some interview, report, things like that. 
We finish here the data analysis and next we present our final considerations.

\section{Final remarks}

Now to finish our reflection, we think that it is necessary to rethink the role of the English language in the school curriculum, because the way it has been proposed has provoked reactions both on the part of teachers and learners.

Regarding discourses, we think it is important to be careful not to spread misconceptions on the teaching of English such as why do I need to learn English? Or is it impossible to learn English at school? The great difference between discourse and practice is what will make possible changes, upon taking into account the factors related with teachers attitudes as well, especially the logistic factors, such as the textbook, load class, the methodology etc, which influence somehow the attitudes mentioned in this paper.

It is necessary to understand that the English language teaching/learning setting is full of beliefs and attitudes, as we have said, both on the part of teachers and learners and they might emerge because of the factors mentioned here. Based on this, we may assure that beliefs and attitudes influence teacher's practices and the way learners learn a language.

We have to say as well that we have adopted the conception of attitude as an evaluative reaction towards a referent, based on beliefs and opinions and individual develop on a referent, as suggested by Gardner (1985). Thus, 'attitude' concerns the way the teacher evaluates his/her practice, his/her students, the textbook, the language itself he/she teaches.

This way, while we propose reflection with the teacher, through an ongoing monitoring of the teaching practice, under the form of academic research, we think it is possible to contribute so that the surveyed groups can improve their pedagogical actions, and, thus, optimize their practices. Therefore, it will always be relevant to understand teachers' beliefs and attitudes toward the English language teaching/learning process.

\section{References:}

1. Abidin, M. J. Z.; Pour-Mohammadi, M.; Alzwari, H. (2012). ELF Students' attitudes towards learning English language: the case of Lybian secondary students. Asian social science. v. 8, no. 2, p. 119134.

2. Adolphs, S. "I don't think I should learn all this". (2005). A longitudinal view of attitudes towards "native speaker" English. In: Gnutzmann, C.; intemann, F. (Ed.) The globalization of English and the English language classroom (pp. 119-132). Narr. 
3. Ahmed, S. (2015). Attitudes towards English language learning among ELF learners at UMSKAL. Journal of education and practice. v. 6, no. 18, p. 6-16.

4. Allport, G. W. (1954). The historical background of modern social psychology. In: Lindzey, G. (Ed.) Handbook of social psychology (pp. 3-56). Cambridge University Press.

5. Anjos, F. A. (2013). "Pra que aprender inglês se não vou para os Estados Unidos": Um estudo sobre atitudes de alguns alunos da escola pública em relação à aprendizagem do inglês como língua estrangeira. Salvador: UFBA. 2013. 152 f. Master's Thesis. Mestrado em Língua e Cultura. Instituto de Letras, Universidade Federal da Bahia (UFBA).

6. Anjos, F. A. (2018). "Passei o semestre todo estudando o verbo to be": atitudes, (des)motivação e orientação para aprender inglês de alguns bacharelandos da UFRB. Doctoral Dissertation. Universidade Federal da Bahia (UFBA).

7. Cançado, M. (1994). Um estudo sobre a pesquisa etnográfica em sala de aula. Trabalhos em linguística aplicada. n. 23, p. 55-69.

8. Corbin, J.; Holt, N. L. (2015).Teoria fundamentada em dados. In: B. Somekh; C. Lewin (Ed.) Teoria e métodos de pesquisa social (2nd ed., pp. 161-169). Vozes.

9. Dörnyei, Z. (1994). Motivation and motivating in the foreign language classroom. The modern language journal, 78, iii, p. 273-284.

10. Fairclough, N. (2001). Discurso e mudança social. Universidade de Brasília.

11. Freire, P. (1996). Pedagogia da autonomia: saberes necessários à prática educativa. 15th ed. Paz e Terra.

12. Gardner, R. C. (1985). Social psychology and second language learning: the role of attitudes and motivation. Edward Arnold.

13. Giroux, H. A. (1997). Os professores como intelectuais: rumo a uma pedagogia crítica da aprendizagem. Translated by Daniel Bueno. Artmed.

14. Hosseini, S.B.; Pourmandnia, D. (2013). Language learners' attitudes and beliefs: brief review of the related literature and frameworks. International Journal on new trends and education and their implications, vol. 4, no. 4, p. 63-74.

15. Karaham, F. (2007). Language attitudes of Turkish students toward the English language and its usage in Turkish context. Journal of Arts and Sciences, vol. 7, p.73-87.

16. Kramsch, C.; Sullivan, P. (1996). Appropriate pedagogy. ELT journal, vol 5, July, Oxford University Press, p. 199-212. 
17. Liu, M. (2007). Chinese student's motivation to learn English at the tertiary level. Asian EFL Journal, vol. 9(1), 126-146.

18. Mackenzie, R. M. (2010). The social psychology of English as a global language. Attitudes, awareness and identity in the Japanese context. Northumbria University.

19. Matsuda, A. (2003). The ownership of English in Japanese secondary schools. World Englishes, vol. 21, no. 3, p. 436-440.

20. Moita Lopes, L. P. (2003). Discursos de identidades: discurso como espaço de construção de gênero, sexualidade, raça, idade e profissão na escola e na família. Campinas. Mercado de Letras.

21. Pennycook, A. (1998). English and the discourses of colonialism. Routledge.

22. Pennycook, A.(2006). Uma linguística aplicada transgressiva. In: Moita Lopes, L. P. (Ed.). Por uma linguística aplicada indisciplinar (pp. 67-84). Parábola Editorial.

23. Rajagopalan, K. (2003). Por uma linguística crítica. Linguagem, identidade e a questão ética. Parabola.

24. Ribeiro, M. M. S. (2006). Atitudes e motivação: fatores intrínsecos da interação professor/aluno. Universidade Estadual de Campinas.

25. Siming, I. A.; Anthony, E. M.; Channa, M. A.; Chandio, A. A.; Lashari, A. A.; Al-Mamary, Y. H. (2015). Motivation towards learning English as second language among science undergraduates' Pakistan: a case study of QUEST Pakistan. Medwell journals, n. 10, v. 6, p. 718722.

26. Telles, J. (2002).“É pesquisa é? Ah, não quero não, bem!” - Sobre pesquisa acadêmica e sua relação com a prática do professor de línguas. Linguagem e ensino, v.5, n. 2, p. 91-116.

27. Tsuda, S. (2003). Attitudes toward English Language Learning in Higher Education in Japan (2): raising awareness of the notion of global English. Intercultural communication Studies. XII-3, p. 61-75.

28. Yee, M.; Young, C. (2006). Macao students' attitudes toward English: a post-1999 survey. World Englishes. v. 25, n. 3, p. 479-490.

29. Vaezi, Z. (2008). Language learning motivation among Iranian undergraduate students. World applied sciences journal, 5 (1), p. 5461.

30. Walker, A. W..; Shaferd., J.; Liams, M. (2004). "Not In My Classroom": Teacher attitudes towards English language learners in the mainstream classroom. $N A B E$ journal of research and practice, $2: 1$, p. $130-131$. 
Special Edition: 5TH COLLOQUIUM OF THE RESEARCH GROUP BODY AND IMAGE IN

DISCOURSE: CECI N'EST PAS UNE PIPE \& 4TH SYMPOSIUM ON TRANSCULTURALITY, LANGUAGE AND EDUCATION: THINKING (AND DOING) OTHERWISE

31. Wu Man-Fat, M. (2004). An exploration of the role of integrative motivation in the achievement of English language learners in Hong Kong. Karen's linguistics Issues, p. 6-23. 